\title{
The Mechanism of Action of Proline Suppressors in Aspergillus nidulans
}

\author{
By P. WEGLENSKI* \\ John Innes Institute, Bayfordbury, Hertford, Hertfordshire
}

(Accepted for publication 12 November 1966)

\begin{abstract}
SUMMARY
Effects of mutations in three independent proline suppressor loci were studied. Mutants of the su-6 locus were almost completely deficient in ornithine transcarbamylase activity and mutants of the su-19 locus produced ornithine $\delta$-transaminase constitutively or semiconstitutively; this latter enzyme was strongly induced by arginine in the wild type. The su- 6 and $s u-19$ suppressor mutations were all recessive. Dominant and recessive mutants of the third suppressor locus, su-2, showed higher activities of arginase and ornithine $\delta$-transaminase than did the wild type. It is suggested that in all three cases the enzyme alterations caused by the suppressor mutations allow the synthesis of proline by an alternative route, replacing the blocked major pathway.
\end{abstract}

\section{INTRODUCTION}

One of the mechanisms proposed by Wagner \& Mitchell (1964) for explaining the mode of action of suppressor genes was that they open up alternative pathways, bypassing the metabolic block caused by the suppressed mutation. In fact, most suppressors studied have been found to act in different ways, and the only case known where the above explanation can be applied is that of the suppressors of acetate mutants in Neurospora crassa (Strauss \& Pierog, 1954). However, there are several cases known where the biochemical situation leads one to suspect the possibility of the occurrence of this mechanism of suppression. One of them is the synthesis of proline.

The results of intensive investigations carried out on various microorganisms (Davis, 1955; Vogel, 1955; Strecker, 1957; Vogel \& Kopac, 1959; Middelhoven, 1963; Vogel \& Vogel, 1963; Middelhoven, 1964) showed that proline is synthesized from glutamate through glutamic- $\gamma$-semialdehyde (GSA) and $\Delta^{1}$-pyrroline-5-carboxylic acid. This is a major route of proline synthesis, but proline can also be formed from ornithine via GSA (Fig. 2). This alternative route operates in the presence of an excess of exogenously supplied ornithine or arginine when, as was found by AnderssonKotto \& Ehrensvard (1963) in the wild strain of Neurospora crassa, the major route is almost completely replaced by the alternative one.

In Aspergillus nidulans two distinct loci, pro-1 and pro-3, are known (Forbes, 1956), mutants of both loci responding to proline, ornithine, citrulline or arginine. According to the biochemical data they should be considered as blocked between glutamate and GSA. The occurrence of mutants of this kind, known also in other micro-organisms,

* Present address: Department of Genetics, Warsaw University, Warsaw, Poland. 
proves that the endogenously produced ornithine or arginine is not sufficient to satisfy the proline requirements of the organism when the major proline route is blocked. In this particular situation one can expect that some mutations affecting the pathway of arginine synthesis and causing, for example, the accumulation of arginine, should act as proline suppressors.

The aim of the experiments presented in this paper was to find whether the above consideration is true for proline suppressors in Aspergillus nidulans. The genetical analysis of these suppressors involving mapping and studies on complementation was done previously (Weglenski, 1966). It was established that mutants of the three suppressor loci so far mapped are non-specific, i.e. they suppress mutants of pro- 1 and pro-3 loci. The idea that their action involves alternative metabolic pathways is thus quite plausible. All mutants in two of the suppressor loci (su-6 and su-19) are recessive, but in the third (su-2) both dominant (symbol $S U$ ) and recessive (su) mutations were mapped. Other symbols used are: $p r o=$ proline; $p a b=p$-aminobenzoic acid; ade= adenine; $p h e=$ phenylalanine $;$ bio $=$ biotin.

\section{METHODS}

Material. All suppressor mutants of Aspergillus nidulans used in this work were obtained as spontaneous mutants from the pro-6 pab-9 bio- 1 strain; pro- 6 is an allele of the pro-1 mutant and was originally obtained from the Department of Genetics, Glasgow University. The strains used for the enzyme assays were of the $\mathrm{pro}^{+} \mathrm{su}^{+}, \mathrm{prosu}^{+}$, prosu and pro $^{+}$su types, all marked additionally with the ade- $9, y$ and phe- 2 mutations.

Media. Liquid minimal medium for culture of mycelium was the same as described by Cove (1966) with addition of $\mathrm{NaNO}_{3} 6 \mathrm{~g} .1$. medium. The final concentration of an amino acid when present in the medium was $0.002 \mathrm{M}$. All other media used were as described by Pontecorvo et al. (1953).

Culture and harvesting of mycelium. Mycelium was grown in one litre or 250-ml. Erlenmayer flasks containing 200 or $100 \mathrm{ml}$. medium, respectively. Flasks were inoculated with a heavy conidial suspension in water and were incubated at $30^{\circ}$ for $35-40 \mathrm{hr}$ (unless indicated otherwise) on a rotary shaker operating at $160 \mathrm{rev} . / \mathrm{min}$. After incubation the medium was filtered off and the mycelium rinsed with distilled water. Blotted mycelial pads were stored at $-20^{\circ}$.

Enzyme extraction. Frozen mycelium mixed with glass powder was ground by hand in a chilled mortar with about 6 vol. of appropriate buffer. The resulting slurry was then centrifuged at $14,000 \mathrm{~g}$ for $20 \mathrm{~min}$ at $4^{\circ}$ and the supernatant fluid used for enzyme assays.

Assays of ornithine transcarbamylase (OTC). The reaction mixture for OTC contained $10 \mu$ mole ornithine $\mathrm{HCl}, 10 \mu$ mole carbamoyl phosphate, $100 \mu$ mole tris $\mathrm{HCl}$ ( $\mathrm{pH} 8.3$ ) and $0.3 \mathrm{ml}$. enzyme extract (equiv. $0.6 \mathrm{mg}$ protein) in $0.1 \mathrm{M}$-sodium phosphate buffer ( $\mathrm{pH} \mathrm{8.0)}$; total volume of reaction mixture $1.0 \mathrm{ml}$. After incubation at $35^{\circ}$ for $15 \mathrm{~min}$. the reaction was stopped by adding $2 \mathrm{ml} .0 .5 \mathrm{M}$-perchloric acid solution and the precipitate removed by centrifugation. Citrulline was estimated colorimetrically by the method of Archibald (1944) by using an EEL colorimeter, blue filter no. 602 .

Assay of ornithine $\delta$-transaminase (OTA). The reaction mixture for OTA contained $10 \mu$ mole ornithine $\mathrm{HCl}, 10 \mu$ mole $\alpha$-ketoglutarate, $50 \mu$ mole potassium phosphate (pH 8.0), $2 \mu$ mole pyridoxal -5 - phosphate, $0.2 \mathrm{ml}$. enzyme extract (equiv. $0.4 \mathrm{mg}$. 
protein) in a total volume $0.5 \mathrm{ml}$. Enzyme extracts were prepared in $0.1 \mathrm{M}$-potassium phosphate buffer $(\mathrm{pH} 8 \cdot 0)$. The mixture was incubated at $37^{\circ}$ for $10 \mathrm{~min}$. and the formation of GSA was shown with $o$-aminobenzaldehyde and measured according to the method of Albrecht, Scher \& Vogel (1962).

Assay of arginase. The reaction mixture for arginase contained $10 \mu$ mole arginine $\mathrm{HCl}(\mathrm{pH} \mathrm{9.5)}$ and $0.2 \mathrm{ml}$. enzyme extract (equiv. 0.4 protein) in total volume $0.7 \mathrm{ml}$. Enzyme extracts were prepared in $0.002 \mathrm{M}$-maleic acid (pH 7.0) containing $1 \mu$ mole $\mathrm{MnCl}_{2} / \mathrm{ml}$., and were dialysed for $3 \mathrm{hr}$ against three changes of the same solution. Incubation was for $10 \mathrm{~min}$. at $37^{\circ}$, and the reaction was stopped by adding $0.3 \mathrm{ml}$. $6 \mathrm{~N}-\mathrm{HCl}$. The resulting protein precipitate was removed by centrifugation and the appropriately diluted supernatant fluid used for the determination of ornithine by the method of Chinard (1952).

Determination of protein. Protein estimations were made according to the Lowry et al. (1951) method, with crystalline bovine serum albumin as a standard.

\section{RESULTS}

Effect of suppressor mutations on ornithine transcarbamylase (OTC) activity

Strains carrying the su- 6 mutation show very poor growth on minimal medium. The growth of these strains can be stimulated by arginine (Weglenski, 1966). This suggested that they are deficient in one of the enzymes in the arginine pathway. It was found that the su- 6 mutation affects the activity of OTC, the enzyme which converts ornithine to citrulline. The specific activities of OTC in the su-6 mutants are shown, together with those of the wild strain and of the other suppressor strains, in Table 1.

Table 1. Aspergillus nidulans: specific activities of ornithine transcarbamylase (OTC) in wild-type and suppressor strains

\begin{tabular}{|c|c|c|}
\hline $\begin{array}{l}\text { Suppressor } \\
\text { locus }\end{array}$ & $\begin{array}{l}\text { Genotype } \\
\text { of strain }\end{array}$ & $\begin{array}{l}\text { OTC activity } \\
(\mu \text { moles } \\
\text { citrulline } / \mathrm{mg} \text {. } \\
\text { protein } / \mathrm{hr})\end{array}$ \\
\hline . & $\mathrm{pro}^{+} \mathrm{su}^{+}$ & $44 \cdot 0$ \\
\hline$s u-6$ & $\begin{array}{l}\text { pro-6su-6 } \\
\text { pro-6su-16 } \\
\text { pro }^{+} \text {su-6 } \\
\text { pro }^{+} s u-16\end{array}$ & $\begin{array}{l}1 \cdot 5 \\
1.8 \\
0.7 \\
0.9\end{array}$ \\
\hline su-19 & $\begin{array}{l}\text { pro-6su-19 } \\
\text { pro-6su-21 } \\
\text { pro-6su-25 }\end{array}$ & $\begin{array}{l}59 \cdot 0 \\
34 \cdot 0 \\
40 \cdot 0\end{array}$ \\
\hline$s u-2$ & $\begin{array}{l}\text { pro-6su-2 } \\
\text { pro-6su-17 } \\
\text { pro-6SU-1 } \\
\text { pro-6SU-8 }\end{array}$ & $\begin{array}{l}59 \cdot 0 \\
42 \cdot 0 \\
45 \cdot 0 \\
43 \cdot 2\end{array}$ \\
\hline
\end{tabular}

Effects of suppressor mutations on ornithine $\delta$-transaminase (OTA) activity

The activities of OTA in various strains are given in Table 2. This enzyme was inducible by arginine in all strains, though the induction in the strains carrying a mutation of the $s u-2$ locus seemed to be somewhat less effective. Strains carrying a mutation of the su-19 locus showed a very high OTA activity when grown on minimal medium; in one case (pro-6su-25) the activity was equal to the fully-induced value of 
Table 2. Aspergillus nidulans specific activities of ornithine $\delta$-transaminase $(O T A)$ in pro $^{+} \mathrm{su}^{+}$, prosu $^{+}$, prosu and pro ${ }^{+}$su strains grown on minimal medium (MM) and media supplemented as indicated

\begin{tabular}{|c|c|c|c|c|c|}
\hline \multirow{3}{*}{$\begin{array}{l}\text { Suppressor } \\
\text { locus }\end{array}$} & \multirow{3}{*}{$\begin{array}{l}\text { Genotype } \\
\text { of strain }\end{array}$} & \multicolumn{4}{|c|}{ Media } \\
\hline & & MM & + proline & +ornithine & + arginine \\
\hline & & \multicolumn{4}{|c|}{ OTA activity (m $\mu$ moles GSA/mg. protein/min.) } \\
\hline . & $\mathrm{pro}^{+} \mathrm{su}^{+}$ & $20 \cdot 6$ & $6 \cdot 1$ & $13 \cdot 5$ & $280 \cdot 0$ \\
\hline . & pro-6su+ & . & $47 \cdot 6$ & $14 \cdot 9$ & $312 \cdot 0$ \\
\hline$s u-6$ & $\begin{array}{l}\text { pro-6su-6 } \\
\text { pro-6su-16 } \\
\text { pro }^{+} \text {su-6 }\end{array}$ & $\begin{array}{l}38 \cdot 2 \\
35 \cdot 1 \\
15 \cdot 1\end{array}$ & $\begin{array}{l}35 \cdot 1 \\
29 \cdot 2 \\
10 \cdot 1\end{array}$ & $\begin{array}{l}15 \cdot 2 \\
14 \cdot 6 \\
14 \cdot 6\end{array}$ & $\begin{array}{l}264 \cdot 0 \\
289 \cdot 0 \\
290 \cdot 2\end{array}$ \\
\hline su-19 & $\begin{array}{l}\text { pro-6su-19 } \\
\text { pro-6su-21 } \\
\text { pro-6su-25 }\end{array}$ & $\begin{array}{l}143 \cdot 0 \\
146 \cdot 0 \\
295 \cdot 2\end{array}$ & $\begin{array}{l}140.8 \\
152.5 \\
295 \cdot 4\end{array}$ & $\begin{array}{r}83 \cdot 4 \\
112 \cdot 8 \\
216 \cdot 0\end{array}$ & $\begin{array}{l}300 \cdot 0 \\
287 \cdot 0 \\
295 \cdot 0\end{array}$ \\
\hline$s u-2$ & $\begin{array}{l}\text { pro-6su-2 } \\
\text { pro-6su-17 } \\
\text { pro- } 6 S U-1 \\
\text { pro-6SU-8 } \\
\text { pro }^{+} s u-2 \\
\text { pro }^{+} S U-1\end{array}$ & $\begin{array}{l}47 \cdot 7 \\
48 \cdot 0 \\
50 \cdot 1 \\
43 \cdot 9 \\
34 \cdot 4 \\
48 \cdot 2\end{array}$ & $\begin{array}{l}32 \cdot 3 \\
19 \cdot 2 \\
34 \cdot 0 \\
36 \cdot 5 \\
28 \cdot 1 \\
66 \cdot 1\end{array}$ & $\begin{array}{l}16 \cdot 1 \\
14 \cdot 1 \\
22 \cdot 4 \\
28 \cdot 0 \\
32 \cdot 6 \\
38 \cdot 1\end{array}$ & $\begin{array}{l}185 \cdot 6 \\
206 \cdot 0 \\
212 \cdot 0 \\
205 \cdot 5 \\
167 \cdot 1 \\
195 \cdot 0\end{array}$ \\
\hline
\end{tabular}

the enzyme. Mutations in the $s u-2$ locus caused an approximately twofold increase of the OTA activity in comparison with that in the wild strain, whether a dominant or a recessive suppressor mutation was present. OTA was repressed by proline in the wild strain. There was no repression by proline of this enzyme in $s u-19$ strains or in $s u-2$ strains of the $\mathrm{pro}^{+} \mathrm{su}$ type. However, in the strains of prosu type carrying the mutation

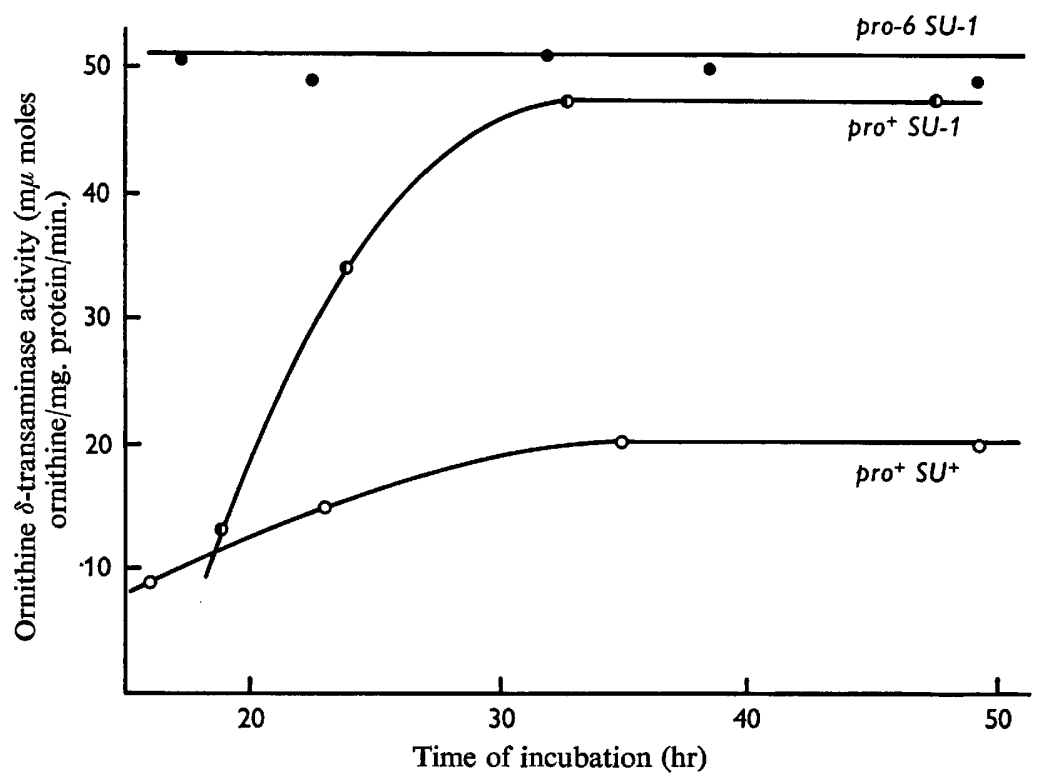

Fig. 1. Aspergillus nidulans: specific activities of ornithine $\delta$-transaminase $\mathrm{pro}^{+} \mathrm{SU}^{+}(-\mathrm{O} \longrightarrow)$ pro $^{+} S U-1(-\infty-)$ and pro- $6 S U-1(-\bullet)$ strains. 
of su-2 locus slight repression was observed. The pro- 6 mutation itself caused an increase in OTA activity, as best indicated by comparison of the figures obtained for pro- $6 \mathrm{su}-6$ and $\mathrm{pro}^{+} \mathrm{su}-6$ strains. The separate effect of the pro- 6 mutation was also seen by comparing the OTA activity in young cultures of strains of the prosu and $\mathrm{pro}^{+} \mathrm{su}$ types, where $s u$ represents any mutation of the $s u-2$ locus (Fig. 1). No qualitative differences between the strains tested were observed in the response of OTA to the presence of ornithine. In all cases a marked decrease of activity was observed.

Table 3. Aspergillus nidulans: specific activities of arginase in $\mathrm{pro}^{+} \mathrm{su}^{+}$, prosu ${ }^{+}$and pro $^{+}$su strains grown on minimal medium (MM) and media supplemented as indicated

\begin{tabular}{|c|c|c|c|c|c|}
\hline \multirow{3}{*}{$\begin{array}{l}\text { Suppressor } \\
\text { locus }\end{array}$} & \multirow{3}{*}{$\begin{array}{l}\text { Genotype } \\
\text { of strain }\end{array}$} & \multicolumn{4}{|c|}{ Media } \\
\hline & & MM & + proline & +ornithine & + arginine \\
\hline & & \multicolumn{4}{|c|}{$\begin{array}{l}\text { Arginase activity (m } \mu \text { moles ornithine/mg. } \\
\text { protein/min.) }\end{array}$} \\
\hline & $\begin{array}{l}\text { pro }^{+} s u^{+} \\
\text {pro- } 6 \text { su }^{+}\end{array}$ & 11 & $\begin{array}{r}6 \\
240\end{array}$ & $\begin{array}{l}51 \\
54\end{array}$ & $\begin{array}{l}560 \\
530\end{array}$ \\
\hline$s u-6$ & pro $^{+}$su-6 & 6 & 6 & 7 & 490 \\
\hline$s u-19$ & pro-6su-19 & 51 & 332 & 246 & 595 \\
\hline$s u-2$ & $\begin{array}{l}\text { pro-6su-2 } \\
\text { pro-6SU-1 } \\
\text { pro-6SU-8 } \\
\text { pro }^{+} s u-2 \\
\text { pro }^{+} S U-1\end{array}$ & $\begin{array}{l}40 \\
64 \\
54 \\
42 \\
72\end{array}$ & $\begin{array}{r}98 \\
150 \\
120 \\
48 \\
52\end{array}$ & $\begin{array}{r}70 \\
52 \\
74 \\
125 \\
101\end{array}$ & $\begin{array}{l}532 \\
520 \\
540 \\
505 \\
489\end{array}$ \\
\hline
\end{tabular}

\section{Effects of suppressor mutations on arginase activity}

Arginase was assayed in the wild strain and various mutant strains grown on minimal medium and on media supplemented with proline, ornithine or arginine. The results (Table 3) show that, in comparison to the wild type, arginase had lower activity in the su- 6 strain and about 4-6 times higher in the su-2 and su-19 strains. In the case of the $s u-2$ locus the increase of the enzyme activity was due to the presence of the suppressor mutations, as indicated by comparison of the figures for the strains of the prosu and pro $^{+} s u$ types. In the case of the $s u-19$ locus no strain of the pro ${ }^{+}$su type was available (pro-6 and su-19 loci are closely linked which makes the selection of the pro ${ }^{+}$su-19 strain difficult) and therefore it is not clear whether the high activity of arginase in the pro- 6 su- 19 strain should be ascribed to the $s u-19$ or to the pro- 6 mutation. The comparison of the figures obtained for the wild and pro- 6 su strains grown in the presence of ornithine makes it obvious that the pro- 6 mutation must be taken into consideration when arginase activity is concerned. The exogenously supplied proline had a very strong effect on arginase activity, causing repression of the enzyme synthesis in the wild strain and a significant induction in all strains carrying the pro- 6 mutation.

Arginase activity was increased when the enzyme extracts were incubated before assay at $37^{\circ}$ or $50^{\circ}$. When pre-incubation at $37^{\circ}$ was used the activity of the enzyme reached a maximum after 15-20 min., and further pre-incubation caused no change in activity. At $50^{\circ}$ the activity maximum was reached after 2-4 min. When manganese was omitted from the buffer used for extraction, activation did not occur. The factor by which pre-incubation increased the activity was very similar in all strains tested; one 
set of results is given in Table 4. This being so, and since the pre-incubation results were not very reproducible, most of the work, including that reported in Table 3, was done without pre-incubation.

Table 4. Aspergillus nidulans: specific activities of arginase in wild-type and suppressor strains after $30 \mathrm{~min}$. pre-incubation at $37^{\circ}$ and after $3 \mathrm{~min}$. pre-incubation at $50^{\circ}$

\begin{tabular}{|c|c|c|c|}
\hline & & e-incuba & \\
\hline & None & $\begin{array}{c}37^{\circ}, \\
30 \mathrm{~min} .\end{array}$ & $\begin{array}{l}50^{\circ} \text {, } \\
3 \mathrm{~min} .\end{array}$ \\
\hline Genotype & $\begin{array}{l}\text { Argi } \\
\text { orni }\end{array}$ & $\begin{array}{l}\text { activity } \\
/ \mathrm{mg} \text {. pro }\end{array}$ & $\begin{array}{l}\text { moles } \\
\text { /min.) }\end{array}$ \\
\hline pro $^{+} s u^{+}$ & 11 & 40 & 120 \\
\hline pro $^{+} s u-2$ & 40 & 170 & 370 \\
\hline $\mathrm{pro}^{+} \mathrm{SU}-\mathrm{l}$ & 72 & 290 & 560 \\
\hline
\end{tabular}

\section{Effects of suppressor mutations on arginine content in the mycelium}

Free arginine content in the mycelium of the wild strain of Aspergillus nidulans and of suppressor strains was compared after separation of the amino acids of boiled mycelium extracts by high voltage electrophoresis and treating the resulting electrophoretogram with the arginine-specific stain according to the method of Irreverre (1965). The arginine spots seemed to be identical in intensity for all strains, with the exception of strains carrying su- 6 mutations where the colour obtained appeared to be markedly weaker (comparison by eye).

A second approach to this problem was to investigate canavanine resistance in the wild strain and in two suppressor strains, one carrying a dominant and the other one a recessive mutation at the $s u-2$ locus. It was assumed that strains producing more arginine should be more resistant to canavine, an arginine analogue, as the inhibition of growth caused by canavine is of a competitive type (Schwartz \& Maas, 1960). The results are shown in Table 5. Expressing the inhibition as the factor by which canavanine decreased the mycelial weight in $24 \mathrm{hr}$ cultures the figures are 4.0 for the wild strain, and $10 \cdot 0$ and $22 \cdot 8$ for recessive and dominant suppressor strains, respectively.

Table 5. Aspergillus nidulans: the dry weight of mycelium of wild-type and suppressor strains obtained from cultures without and with canavanine

\begin{tabular}{|c|c|c|c|c|}
\hline \multirow{3}{*}{$\begin{array}{l}\text { Genotype } \\
\text { of strain } \\
\text { pro }^{+} s u^{+}\end{array}$} & \multirow{3}{*}{$\begin{array}{c}\text { Presence of } \\
\text { canavanine } \\
(100 \mu \mathrm{g} / \mathrm{ml} .) \\
+ \\
-\end{array}$} & \multicolumn{3}{|c|}{ Time of incubation (hr) } \\
\hline & & \multicolumn{3}{|c|}{ Mycelium (mg. dry wt.) } \\
\hline & & $\begin{array}{l}12 \cdot 0 \\
47 \cdot 6\end{array}$ & $\begin{array}{r}62 \cdot 0 \\
225 \cdot 0\end{array}$ & $\begin{array}{r}89.4 \\
390.0\end{array}$ \\
\hline pro $^{+}$su-2 & $t$ & $\begin{array}{r}2 \cdot 4 \\
24 \cdot 0\end{array}$ & $\begin{array}{r}42 \cdot 0 \\
186 \cdot 2\end{array}$ & $\begin{array}{r}99.6 \\
324.2\end{array}$ \\
\hline pro $^{+} S U-I$ & + & $\begin{array}{r}2 \cdot 1 \\
46 \cdot 8\end{array}$ & $\begin{array}{r}30.1 \\
182.9\end{array}$ & $\begin{array}{l}120 \cdot 0 \\
363.6\end{array}$ \\
\hline
\end{tabular}




\section{DISCUSSION}

The modes of action of all suppressors studied in this work have one common feature, i.e. the suppressors all affect the pathway of arginine synthesis or arginine break-down in a way that permits the synthesis or proline by the alternative route (Fig. 2). In the case of the su-6 mutations, which affect the ornithine transcarbamylase activity, this is achieved by decreasing the rate of arginine synthesis from ornithine and thus enhancing the accumulation of ornithine which in these circumstances

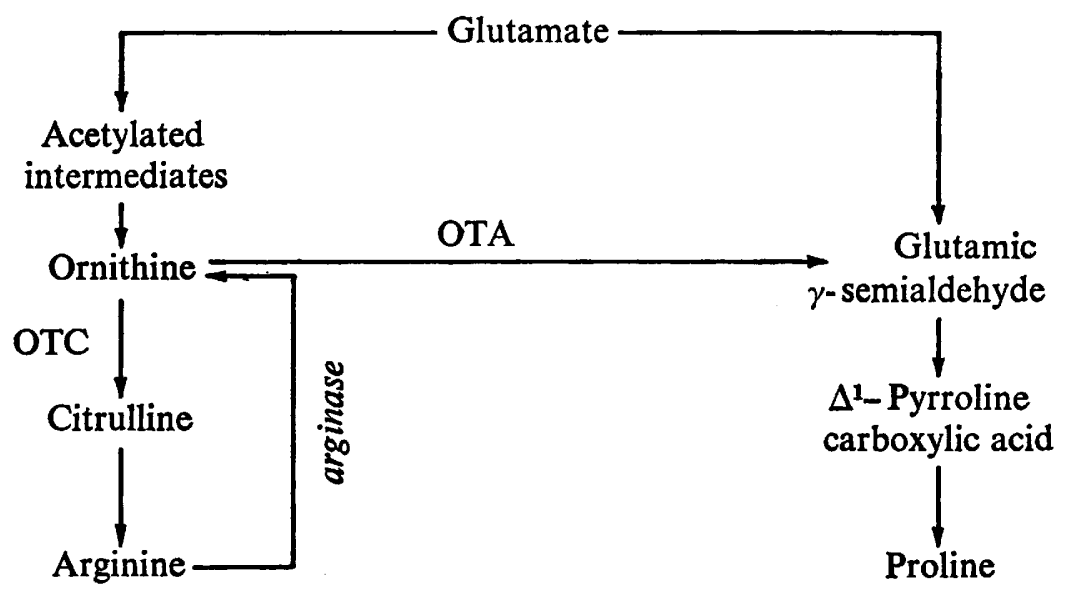

Fig. 2. Aspergillus nidulans: the pathway of proline and arginine synthesis. OTC, Ornithine transcarbamylase; OTA, ornithine $\delta$-transaminase.

becomes available for transmutation to glutamic $\delta$-semialdehyde in the proline pathway. The same mechanism of suppression was described by Davis (1962) in Neurospora crassa, where the suppressor $s$, suppressing some of the pyrimidine mutants and the proline mutants of the same type as those studied in this work, was the mutant affecting the level of ornithine transcarbamylase.

The $s u$-19 suppressor can be considered as the ornithine $\delta$-transaminase regulator gene. Mutations at this locus cause the synthesis of the enzyme to be constitutive (in one case) or semiconstitutive (in two other cases studied). One can assume that there is a competition between ornithine transcarbamylase and ornithine $\delta$-transaminase for ornithine which is entirely or almost entirely converted to citrulline by ornithine transcarbamylase in the wild strain, but partly converted to glutamic $\delta$-semialdehyde by the highly active ornithine $\delta$-transaminase in the $s u-19$ mutants.

The function of the su-2 locus, mutation at which causes an increase of both arginase and ornithine $\delta$-transaminase activities, may be explained in two ways. One possible explanation is that the $s u-2$ mutations lead to an increase in arginine production (caused, for example, by a failure in feedback inhibition of the arginine pathway by arginine) and that the higher activities of the arginine breakdown enzymes are due to induction by the endogenous arginine. The second possibility is that the primary effect of the mutation in the $s u-2$ locus is on the regulation of arginine break-down. The greater sensitivity of suppressor strains to canavanine and the failure to demonstrate 
accumulation of arginine by suppressor strains seem to favour the second possibility for the function of the $s u-2$ locus. Whatever the primary effect of mutation in the $s u-2$ locus, the increase in arginine break-down to ornithine and then to glutamic $\delta$-semialdehyde can explain the suppression of proline mutants in this case. The difference between dominant and recessive mutants of this locus lies most probably in the greater effectiveness of arginine break-down indicated by the higher arginase activity in strains carrying the dominant mutation.

The system of regulation of arginine break-down seems to be rather a complex one. The data obtained indicate the importance of proline or glutamic $\delta$-semialdehyde in controlling the formation of arginase and ornithine $\delta$-transminase. The effect of exogenous proline on that pathway, which was also observed in Neurospora crassa (Andersson-Kotto \& Ehrensvard, 1963) and especially the different effect of proline on the arginase and ornithine $\delta$-transaminase activities in wild strain and in prolinerequiring strains, as well as the effects of ornithine on ornithine $\delta$-transaminase activity cannot be satisfactorily explained at the moment.

I wish to thank Professor J. R. S. Fincham and Dr D. H. Morgan for help and advice during this work as well as for help in preparing the manuscript. My thanks also go to the Leverhulme Trust Fund for the Scholarship I held during the completion of this work.

\section{REFERENCES}

Albrecht, A. M., Scher, W. I. \& Vogel, H. J. (1962). Determination of aliphatic aldehydes by spectrophotometry. Analyt. Chem. 34, 398.

ANDERSSON-KotTo, I. \& Ehrensvard, G. (1963). The integrative effect of some genetical and exogeneous factors upon amino acid formation in Neurospora crassa. Hereditas $50,1$.

ARCHIBALD, R. M. (1944). Determination of citrulline and allantoin and demonstration of citrulline in blood plasma. J. biol. Chem. 156, 121.

ChInARD, F. P. (1952). Photometric estimation of proline and ornithine. J. biol. Chem. 199, 91.

Cove, D. J. (1966). The induction and repression of nitrate reductase in the fungus Aspergillus nidulans. Biochim. biophys. Acta 113, 51.

ForBes, E. C. (1956). Recombination in the pro region in Aspergillus nidulans. Microb. Genet. Bull. 13, 9.

Davis, B. D. (1955). Intermediates in amino acid biosynthesis. Adv. Enzymol. 16, 247.

DAvis, R. H. (1962). Consequences of a suppressor gene effective with pyrimidine and proline mutants of Neurospora. Genetics. 47, 351.

IRREVERRE, F. (1965). A modified Sakaguchi spray. Biochim. biophys. Acta 111, 551.

Lowry, O. H., Rosebrough, N. J., FARR, A. L. \& Randall, R. J. (1951). Protein measurement with the Folin phenol reagent. J. biol. Chem. 193, 265.

MidDlehoven, W. J. (1963). The ornithine pathway in the yeast Candida utilis. Biochim. biophys. Acta 77, 152.

MIDDLEHOVEN, W.J. (1964). The pathway of arginine breakdown in Saccharomyces cerevisiae. Biochim. biophys. Acta 93, 650.

Pontecorvo, G., Roper, J. A., Hemmons, L. M., MacDonald, R. D. \& Bufton, A. W. J. (1953). The genetics of Aspergillus nidulans. Adv. Genet. 5, 141.

SCHWARTZ, J. H. \& MAAS, W. K. (1960). Analysis of the inhibition of growth produced by canavanine in Escherichia coli. J. Bact. 79, 794.

Strauss, B. S. \& Pierog, S. (1954). Gene interactions: the mode of action of the suppressor of acetate requiring mutants of Neurospora crassa. J. gen. Microbiol. 10, 221.

STRECKER, H. J. (1957). The interconversion of glutamic acid and proline. I. The formation of pyrroline carboxylic acid from glutamic acid in Escherichia coli. J. biol. Chem. 225, 825.

VoGEL, H. J. (1955). On the glutamate-proline-ornithine interrelations in various microorganisms. In Amino Acid Metabolism. Baltimore: The Johns Hopkins Press. 
Vogel, R. H. \& KopaC, M. J. (1959). Glutamic $\gamma$-semialdehyde in arginine and proline synthesis in Neurospora. A mutant-tracer analysis. Biochim. biophys. Acta 36, 505.

VOGEL, R. H. \& VOGEL, H. J. (1963). Evidence for acetylated intermediates of arginine synthesis in Neurospora crassa. Genetics 48, 914.

WAGNBR, P. R. \& Mitchell, H. K. (1964). Genetics and Metabolism. New York: John Wiley and Sons Inc.

WeGLENSKI, P. (1966). Genetical analysis of proline mutants and their suppressors in Aspergillus nidulans. Genet. Res. 8, 311. 